\title{
$B$ and $T$ cell values in peripheral blood in Polish mixed breed rabbits
}

\author{
BEATA TOKARZ-DEPTUŁA ${ }^{l}$, PAULINA NIEDŹWIEDZKA-RYSTWEJ ${ }^{l}$, \\ BEATA HUKOWSKA-SZEMATOWICZI, ALICJA TRZECIAK-RYCZEK', \\ MATEUSZ ADAMIAK ${ }^{1}$, WIESEAW DEPTUEA ${ }^{2}$
}

${ }^{1}$ Department of Immunology, Faculty of Biology, University of Szczecin, Poland

${ }^{2}$ Department of Microbiology, Faculty of Biology, University of Szczecin, Poland

\begin{abstract}
Due to the lack of reference values for immunological parameters in Polish mixed breed rabbits, the study was aimed at developing standards for B-cells with CD19+ receptor, and T-cells with CD5+ receptor, and their subpopulations, namely $T$-cells with receptors $C D 4+, C D 8+$ and $C D 25+$ in peripheral blood of Polish mixed breed rabbits, as well as at assessing the impact of four seasons and sex of the animals on such values. The results of the study not only are the source of reference values, but also revealed that the season of the year and sex of the rabbits affect the percentage of $B$-and T-cells and their subpopulations in peripheral blood.
\end{abstract}

Key words: rabbits, lymphocytes, reference values.

(Centr Eur J Immunol 2014; 39 (1): 1-5)

\section{Introduction}

Rabbits are animals of a high economic and laboratory value, whereas in Poland, principally in scientific and diagnostic research, mixed breed rabbits are generally used [1]. It must also be added that although researches involving experiments on laboratory animals are conducted on mice, rats and Guinea pigs, still rabbits are more "convenient" as laboratory animals, for example as more blood can be drawn. Nevertheless, when performing observations on animals, including rabbits, including mixed breed rabbits, it is necessary to know the reference values for immunological factors due to an increased possibility of changes in the elements of the immune system, while in the case of rabbits, including Polish mixed breed rabbits, there are no standards for B- and T-cells. Previous studies in the volume of B- and T-cells in peripheral blood were carried out abroad on rabbits of New Zealand, Fauve de Bourgogne races, as well as LP and V genetic lines (Table 1), while in Poland, exclusively on mixed breed rabbits (Table 2). Such observations were not oriented at determining reference values and no impact of physiological properties of rabbits was analysed, such as sex, age and race, as well as environmental conditions (seasons), even though they were considered, and despite the fact that their impact was documented when analysing haematological factors [2-19]. The studies carried out in Poland on Polish mixed breed rabbits evidenced the impact of age [3,8] and sex [3] of the animals, as well as season of the year [10], while foreign studies on New Zealand and Angora rabbits, as well as Czech races and mixed breed animals also pointed out to the impact of the age $[5,6,11-13,15,19]$, sex $[4,11,14$, $16,17,19]$, and race $[7,9,11,18,19]$, as well as season $[2,16,19]$.

The study was aimed at developing standards for B-cells with CD19+ receptor, and T-cells with CD5+ receptor, and their subpopulations, namely T-cells with receptors CD4+, CD8+ and CD25+ in peripheral blood of Polish mixed breed rabbits, as well as at assessing the impact of four seasons and sex of the animals on such values.

\section{Material and methods}

The study involved 200 Polish mixed breed rabbits, labelled as conventional animals, originating from a licensed farm, remaining under continuous veterinary and zootechnical supervision [20], weighing 3.2-4.2 kg, aged 6-8 months, females and males, in four seasons of the year: spring, summer, autumn, and winter. During the experiment, the animals remained at the vivarium of the Department of Microbiology and Department of Immunology of the Biology Faculty at the University of Szczecin, where zootechnical parameters were in line with the recommended Polish standards developed in line with the European Union Directive as regards temperature and humidity, as well as lighting and size of cages for animals [21]. After transportation to

Correspondence: Paulina Niedźwiedzka-Rystwej, Department of Immunology, Faculty of Biology, University of Szczecin, Felczaka 3 C, 71-412 Szczecin, tel. +48914441605, fax +48914441606 
Table 1. Percentage of B and T cells and subpopulations in peripheral blood of rabbits - foreign data

\begin{tabular}{|c|c|c|c|c|c|c|c|c|c|c|}
\hline \multirow[b]{2}{*}{ Reference } & \multirow[b]{2}{*}{ Age } & \multirow[b]{2}{*}{ Sex } & \multirow{2}{*}{$\begin{array}{l}\text { Number } \\
\text { of } \\
\text { animals }\end{array}$} & \multirow[b]{2}{*}{ Season } & \multirow[b]{2}{*}{ Breed } & \multicolumn{5}{|c|}{ Percentage of $B$ and $T$ cells and subpopulations } \\
\hline & & & & & & $\begin{array}{c}\text { B (receptor } \\
\text { CD19+) }\end{array}$ & $\begin{array}{c}\text { T (receptor } \\
\text { CD5+) }\end{array}$ & $\begin{array}{c}\text { T (receptor } \\
\text { CD4+) }\end{array}$ & $\begin{array}{c}\text { T (receptor } \\
\text { CD8+) }\end{array}$ & $\begin{array}{c}\text { T (receptor } \\
\text { CD25+) }\end{array}$ \\
\hline 28 & no data & female & 65 & no data & $\begin{array}{l}\text { genetic } \\
\text { lines LP } \\
\text { and V }\end{array}$ & $151.7 \times 10^{6} / 1$ & $1306 \times 10^{6} / 1$ & $734.2 \times 10^{6} / 1$ & $328.6 \times 10^{6} / 1$ & $38.77 \times 10^{6} / 1$ \\
\hline 29 & $\begin{array}{l}11-15 \\
\text { mth }\end{array}$ & female & 22 & no data & $\begin{array}{l}\text { Spanish } \\
\text { mixed } \\
\text { breed }\end{array}$ & $96 \times 10^{6} / 1$ & $1191 \times 10^{6} / 1$ & $543 \times 10^{6} / 1$ & $216 \times 10^{6} / 1$ & $14 \times 10^{6 / 1}$ \\
\hline 30 & $\begin{array}{l}1 \text { day } \\
\text { and } 2 \text {, } \\
4,6,8 \\
\text { weeks }\end{array}$ & $\begin{array}{l}\text { no } \\
\text { data }\end{array}$ & 28 & no data & $\begin{array}{c}\text { New } \\
\text { Zealand }\end{array}$ & no data & NS & $29.1 \%$ & $10.9 \%$ & NS \\
\hline 31 & no data & male & no data & no data & $\begin{array}{c}\text { Fauve de } \\
\text { Bourgogne }\end{array}$ & NS & $6314 / \mathrm{mm}^{3}$ & NS & NS & NS \\
\hline
\end{tabular}

NS - not studied

Table 2. Percentage of B and T cells and subpopulations in peripheral blood of rabbits - Polish data

\begin{tabular}{|c|c|c|c|c|c|c|c|c|c|c|c|}
\hline \multirow[b]{2}{*}{ Reference } & \multirow[b]{2}{*}{ Age } & \multirow[b]{2}{*}{ Sex } & \multirow[b]{2}{*}{$\begin{array}{c}\text { Number } \\
\text { of } \\
\text { animals }\end{array}$} & \multirow[b]{2}{*}{ Season } & \multirow[b]{2}{*}{ Breed } & \multicolumn{6}{|c|}{ Percentage of $B$ and $T$ cells and subpopulations } \\
\hline & & & & & & & $\begin{array}{c}\text { B } \\
\text { (receptor } \\
\text { CD19+) }\end{array}$ & $\begin{array}{c}\text { T } \\
\text { (receptor } \\
\text { CD5+) }\end{array}$ & $\begin{array}{c}\mathrm{T} \\
\text { (receptor } \\
\text { CD4+) }\end{array}$ & $\begin{array}{c}\mathrm{T} \\
\text { (receptor } \\
\text { CD8+) }\end{array}$ & $\begin{array}{c}\mathrm{T} \\
\text { (receptor } \\
\text { CD25+) }\end{array}$ \\
\hline \multirow{2}{*}{22} & \multirow{2}{*}{ no data } & \multirow{2}{*}{ male } & \multirow{2}{*}{20} & \multirow{2}{*}{ no data } & \multirow{2}{*}{$\begin{array}{l}\text { Polish } \\
\text { mixed } \\
\text { breed }\end{array}$} & $\bar{x}$ & 1.6 & 40.3 & 32.9 & NS & 0.75 \\
\hline & & & & & & $\pm \mathrm{SD}$ & NS & NS & NS & NS & NS \\
\hline \multirow{2}{*}{23} & \multirow{2}{*}{ 3-5 mth } & \multirow{2}{*}{$\begin{array}{l}\text { male and } \\
\text { female }\end{array}$} & \multirow{2}{*}{20} & \multirow{2}{*}{$\begin{array}{c}\text { spring } \\
\text { (March-June) }\end{array}$} & \multirow{2}{*}{$\begin{array}{l}\text { Polish } \\
\text { mixed } \\
\text { breed }\end{array}$} & $\bar{x}$ & 19.23 & 55.61 & 39.35 & 18.47 & 20.58 \\
\hline & & & & & & $\pm \mathrm{SD}$ & 1.75 & 1.42 & 2.54 & 1.52 & 1.54 \\
\hline \multirow{2}{*}{24} & \multirow{2}{*}{$\begin{array}{l}3-4.5 \\
\text { mth }\end{array}$} & \multirow{2}{*}{$\begin{array}{l}\text { male and } \\
\text { female }\end{array}$} & \multirow{2}{*}{60} & \multirow{2}{*}{$\begin{array}{c}\text { spring } \\
\text { (March-June) }\end{array}$} & \multirow{2}{*}{$\begin{array}{l}\text { Polish } \\
\text { mixed } \\
\text { breed }\end{array}$} & $\bar{x}$ & 11.4 & 55.7 & 39.6 & 14.5 & 11.2 \\
\hline & & & & & & $\pm \mathrm{SD}$ & 4.51 & 15.09 & 5.75 & 2.53 & 3.84 \\
\hline \multirow{2}{*}{25} & \multirow{2}{*}{$\begin{array}{l}3-4.5 \\
\text { mth }\end{array}$} & \multirow{2}{*}{$\begin{array}{l}\text { male and } \\
\text { female }\end{array}$} & \multirow{2}{*}{60} & \multirow{2}{*}{$\begin{array}{l}\text { spring (March- } \\
\text { June), autumn } \\
\text { (September- } \\
\text { October) }\end{array}$} & \multirow{2}{*}{$\begin{array}{l}\text { Polish } \\
\text { mixed } \\
\text { breed }\end{array}$} & $\bar{x}$ & 11.40 & 55.70 & 39.60 & 14.50 & 11.20 \\
\hline & & & & & & $\pm \mathrm{SD}$ & 4.51 & 15.09 & 5.75 & 2.53 & 3.84 \\
\hline \multirow[b]{2}{*}{26} & \multirow[b]{2}{*}{ no data } & \multirow[b]{2}{*}{ no data } & \multirow[b]{2}{*}{20} & \multirow[b]{2}{*}{ no data } & Polish & $\bar{x}$ & 1.6 & 40.3 & 32.9 & NS & 0.75 \\
\hline & & & & & $\begin{array}{l}\text { mixed } \\
\text { breed }\end{array}$ & $\pm \mathrm{SD}$ & NS & NS & NS & NS & NS \\
\hline & $3-4.5$ & male and & & $\begin{array}{l}\text { spring (March- } \\
\text { June), autumn }\end{array}$ & Polish & $\bar{x}$ & 11.4 & 55.7 & 39.6 & 14.5 & 11.2 \\
\hline 27 & mth & female & 60 & $\begin{array}{l}\text { (September- } \\
\text { October) }\end{array}$ & $\begin{array}{l}\text { mixed } \\
\text { breed }\end{array}$ & $\pm \mathrm{SD}$ & 4.51 & 15.09 & 5.75 & 2.53 & 3.84 \\
\hline
\end{tabular}

the Department vivarium, the animals were provided with a two-week adaptation period. The animals were fed with all-mash rabbit feed (16\% Królik z Motycza), at a volume of 0.15-0.20 kg/day, and had unlimited access to water.

The study was carried out twice (seven days each) in four seasons. Blood for tests was drawn by establishing a port from the marginal vein of the ear, in 24-hour intervals, for three consecutive days, at 8:00 AM, namely at hours 0, 24 and $48 \mathrm{~h}$ from commencement of the study. In blood of rabbits, the percentage of CD19+ B-cells, and CD5+ T-cells, as well as their subpopulations - T-cells with receptors CD4+, CD8+ and CD25+ was determined, according to the method described by Deptuła et al. [22] using monoclonal antibodies (mouse anti-rabbit) (Serotec, USA). 
Table 3. Percentage of B and T cells and subpopulations in peripheral blood of rabbits taking into consideration season and sex

\begin{tabular}{|c|c|c|c|c|c|c|c|c|c|c|c|c|c|}
\hline \multirow{2}{*}{\multicolumn{2}{|c|}{$\begin{array}{c}\text { B and } T \text { cells and } \\
\text { subpopulations }\end{array}$}} & \multicolumn{3}{|c|}{ Spring } & \multicolumn{3}{|c|}{ Summer } & \multicolumn{3}{|c|}{ Autumn } & \multicolumn{3}{|c|}{ Winter } \\
\hline & & $\begin{array}{l}\text { female } \\
(25)\end{array}$ & $\begin{array}{c}\text { male } \\
(25)\end{array}$ & $\begin{array}{l}\text { together } \\
(50)\end{array}$ & $\begin{array}{c}\text { female } \\
\text { (25) }\end{array}$ & $\begin{array}{c}\text { male } \\
(25)\end{array}$ & $\begin{array}{l}\text { together } \\
(50)\end{array}$ & $\begin{array}{l}\text { female } \\
\text { (25) }\end{array}$ & $\begin{array}{l}\text { male } \\
(25)\end{array}$ & $\begin{array}{l}\text { together } \\
(50)\end{array}$ & $\begin{array}{c}\text { female } \\
\text { (25) }\end{array}$ & $\begin{array}{c}\text { male } \\
(25)\end{array}$ & $\begin{array}{l}\text { together } \\
(50)\end{array}$ \\
\hline \multirow{2}{*}{$\begin{array}{l}\text { B receptor } \\
\text { CD19+ }\end{array}$} & $\bar{x}$ & 13.01 & 11.44 & $12.23^{\mathrm{b} 1}$ & 11.12 & 10.39 & 10.76 & 12.28 & 12.02 & $12.15^{\mathrm{b} 4 \mathrm{~b} 6}$ & 10.85 & 11.03 & 10.94 \\
\hline & $\pm \mathrm{SD}$ & 1.26 & 1.15 & 1.11 & 0.94 & 0.93 & 0.52 & 0.76 & 2.28 & 0.18 & 1.34 & 1.23 & 0.013 \\
\hline \multirow{2}{*}{$\begin{array}{l}\text { T receptor } \\
\text { CD5+ }\end{array}$} & $\bar{x}$ & 48.99 & 48.99 & $48.99^{\mathrm{b} 2}$ & 52.68 & 50.24 & $51.46^{\mathrm{b} 4}$ & 41.48 & 44.64 & 43.06 & 43.57 & 53.28 & $48.43^{\mathrm{b} 5 \mathrm{~b} 6}$ \\
\hline & $\pm \mathrm{SD}$ & 4.43 & 5.43 & 4.56 & 4.50 & 4.35 & 6.23 & 1.83 & 3.85 & 4.18 & 5.08 & 3.17 & 6.78 \\
\hline \multirow{2}{*}{$\begin{array}{c}\text { T receptor } \\
\text { CD4+ }\end{array}$} & $\bar{x}$ & $39.13^{\mathrm{a}}$ & 21.53 & 30.33 & 40.16 & 39.93 & $40.01^{\mathrm{b} 1}$ & 35.78 & $40.02^{\mathrm{a}}$ & $37.90^{\mathrm{b} 2}$ & 34.15 & $44.74^{\mathrm{a}}$ & $39.45^{\mathrm{b} 3}$ \\
\hline & $\pm \mathrm{SD}$ & 4.14 & 3.04 & 6.54 & 2.57 & 4.07 & 4.16 & 2.39 & 4.11 & 3.48 & 4.03 & 1.67 & 2.49 \\
\hline \multirow{2}{*}{$\begin{array}{l}\text { T receptor } \\
\mathrm{CD} 8+\end{array}$} & $\bar{x}$ & 15.49 & 14.78 & 15.14 & 13.00 & 14.97 & 13.99 & 13.64 & 13.47 & 13.56 & $19.84^{\mathrm{a}}$ & 11.69 & 15.77 \\
\hline & $\pm \mathrm{SD}$ & 2.14 & 3.29 & 2.50 & 1.16 & 2.67 & 1.39 & 0.70 & 2.75 & 1.12 & 5.25 & 4.57 & 3.26 \\
\hline \multirow{2}{*}{$\begin{array}{l}\text { T receptor } \\
\text { CD25+ }\end{array}$} & $\bar{x}$ & 12.07 & 12.34 & 12.20 & $14.86^{\mathrm{a}}$ & 10.83 & 12.85 & 12.06 & 12.24 & 12.15 & 11.69 & 13.23 & 12.46 \\
\hline & $\pm \mathrm{SD}$ & 0.62 & 0.18 & 2.19 & 4.13 & 4.23 & 2.85 & 1.05 & 1.06 & 2.13 & 1.86 & 2.05 & 1.97 \\
\hline
\end{tabular}

The analysed samples were incubated for 45 minutes in ice, rinsed three times with Cell Wash (BD Biosciences, USA) by centrifugation at $200 \mathrm{xg}$. To such prepared cellular sediment, $10 \mu \mathrm{l}$ of rabbit antibodies were added marked against mouse IgG with fluorescein isothiocyanate (FITC). After triple repetition of the rinsing procedure in Cell Wash, $2000 \mu \mathrm{l}$ of lysing solution was added to samples to eliminate erythrocytes (BD FACS Lysing Solution, BD Biosciences, USA). After ten minutes of incubation in the dark, at room temperature, measurement was performed on FACScan flow cytometer by Becton Dickinson (USA) using FACSDiva software.

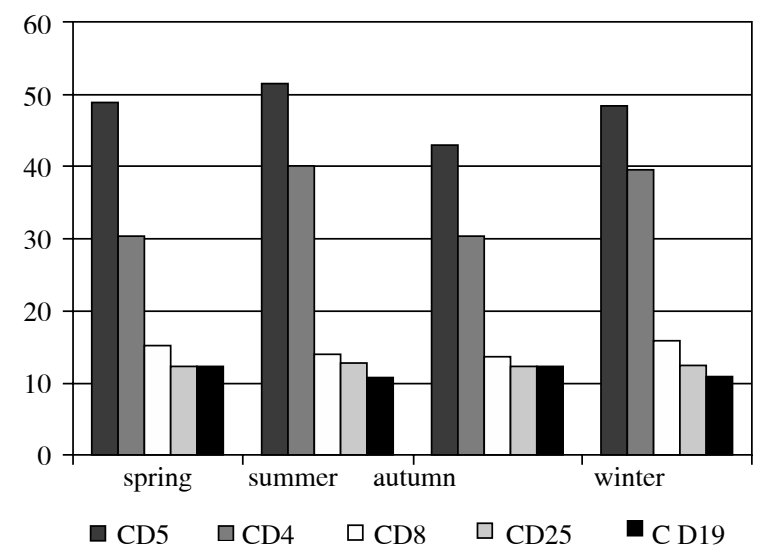

Fig. 1. Values of B and T lymphocytes in Polish mixed breed rabbits in seasons of the year (without considering the sex)
The results of the study on B- and T-cells and their subpopulations in percentage, as obtained from three blood draws from each rabbit (at $0,24,48 \mathrm{~h}$ ), performed twice at the interval of seven days in each season of the year, are presented as average values and standard deviations in Table 3 and in Figs. 1-3, as previously subjected to statistical analysis using $t^{\prime}$ Student test at $p=0.05$.

\section{Results and discussion}

When analysing the results obtained as regards the percentage of CD19+ B-cells and CD5+ T-cells, as well

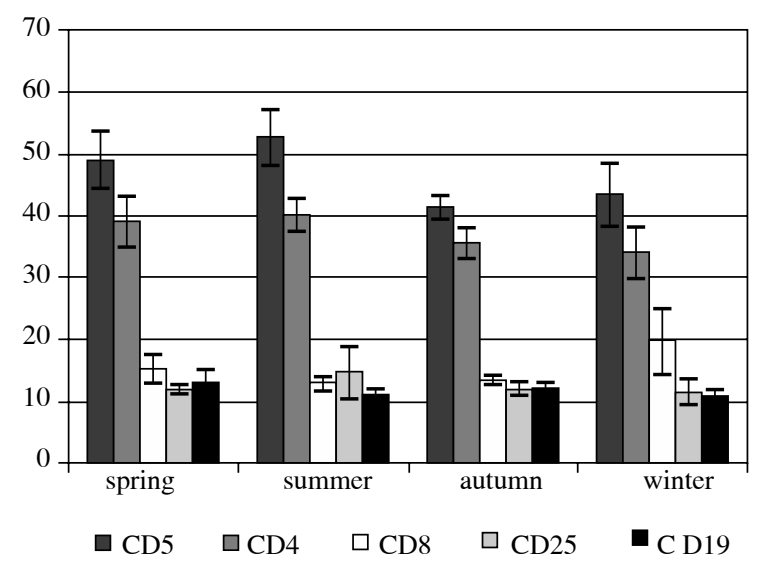

Fig. 2. Values of B and T lymphocytes in females of Polish mixed breed rabbits in seasons of the year 


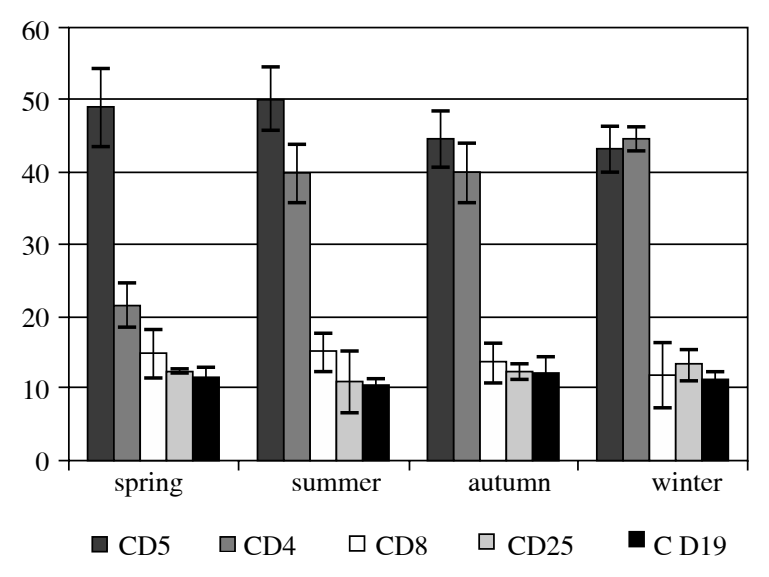

Fig. 3. Values of B and T lymphocytes in males Polish mixed breed rabbits in seasons of the year

as their subpopulations (CD4+ T-cells, CD8+ T-cells, and CD25+ T-cells) (Table 3), it must be stated that the values obtained in Polish mixed breed rabbits can only be compared to the results of studies obtained by Polish authors (Table 2), also carried out on mixed breed rabbits from Poland, which have been presented in the same units as in the present study. In turn, the results of foreign studies (Table 1) regarding such cells, performed on pureblood rabbits (Fauve de Bourgogne and New Zealand) and Spanish mixed breed rabbits, are presented in different units, which renders it impossible to compare them to the present results. When assessing the results in the area of particular blood cells analysed, it must be stated that the values for CD19+ B-cells remain within the range from 10.76 to $12.23 \%$ (Table 3), CD25+ T-cells: within the range from 12.15 to $12.85 \%$ (Table 3 ), and are similar to the results previously obtained in Polish mixed breed rabbits (Table 2), although it must be added that both in the case of CD19+ B-cells and CD25+ T-cells, in the latter studies (Table 2), also much lower values and much higher values (Table 2) than the present ones were recorded (Table 3). In turn, as regards CD5+ T-cells, their values in the present study ranged from 43.06 to $51.46 \%$, CD4+ T-cells - from 30.33 to $40.01 \%$, while CD8+ T-cells - from 13.56 to $15.77 \%$ (Table 3 ). The results obtained for CD5+ T-cells, CD4+ T-cells, and CD8+ T-cells are actually also correlated with the results obtained in the previous studies on Polish mixed breed rabbits (Table 2), but no such fluctuations were determined in them, as recorded with reference to CD19+ B-cells and CD25+ T-cells.

When analysing the results obtained for B- and T-cells and their subpopulations in Polish mixed breed rabbits, in the aspect of the impact of the season (Table 3, Figs. 1-3) and sex of the animals (Table 3, Figs. 2, 3), it must be stated that both the season and sex affect values of the parameters analysed.
Detailed analysis of the impact of the seasons on the analysed elements of peripheral blood in rabbits without considering the sex (Table 3 ) revealed that statistically significant differences between the values obtained in spring and summer refer to CD19+ B-cells and CD4+ T-cells; between spring and autumn - to CD5+ T-cells and CD4+ $\mathrm{T}$-cells, and between spring and winter - to CD4+ T-cells. The assessment also evidenced that the differences between summer and autumn are recorded in the percentage of CD19+ B-cells and CD5+ T-cells, while differences between summer and winter - exclusively in the area of CD5+ T-cells, whereas differences between autumn and winter - as regards CD19+ B-cells and CD5+ T-cells. To recapitulate changes regarding the impact of the seasons on the analysed B- and T-cells and their subpopulations, it can be stated that the season most significantly affects the values of CD5+ T-cells, as for this parameter, four statistically significant changes were recorded; as well as CD19+ B-cells and CD4+ T-cells, where three statistically significant changes were recorded for each of these cells (Table 3). Whereas, when analysing the impact of the seasons on the factors analysed considering sex of the animals (Table 3), it was evidenced that the seasons affect males and females in a different way, as in females, statistically significant values were recorded in spring, summer and winter, while in males exclusively in autumn and winter, and these in females referred to CD4+ T-cells, CD25+ T-cells, and CD8+ $\mathrm{T}$-cells, while in males - to CD4+ T-cells.

The assessment of the impact of sex of the animals on the percentage of B- and T-cells and their subpopulations in peripheral blood of Polish mixed breed rabbits (Table 3) evidenced that more statistically significant values are recorded in the factors analysed in females rather than males, as for females they were recorded in spring for CD4+ T-cells, summer for CD25+ T-cells, and winter for CD8+ T-cells, while in males they were only recorded in autumn and winter and exclusively for CD4+ T-cells. This would confirm observations recorded when assessing the impact of the seasons on the analysed factors in females and males, and points out to the fact that this physiological property (sex) most strongly affects CD4+ T-cells.

To conclude, it must be stated that the values of B- and T-cells and their subpopulations in peripheral blood in Polish mixed breed rabbits remain within the following ranges: for CD19+ B-cells: 10.76-12.23\%, for CD5+ T-cells: 43.0651.46\%, CD4+ T-cells: 30.33-40.01\%, CD8+ T-cells: $13.56-$ $15.77 \%$, whereas for CD25+ T-cells: $12.15-12.85 \%$. Due to the large material which the study involved, the results should constitute reference values for such animals, the more so that they correlate to the values obtained in the previous studies also on mixed breed rabbits (Table 2). The present study also revealed that both the season of the year and sex of the rabbits affect the percentage of B- and T-cells and their subpopulations in peripheral blood. In the case of season of the year, it was observed that this factor principally affects the values of 
CD5+ T-cells and CD19+ B-cells, as well as CD4+ T-cells, differently in males and females. In turn, in the case of sex of the animals, it was recorded that it affects the analysed immunological factors, causing more changes in females, but in both males and females these referred to CD4+ T-cells, whereas in females the changes took place in spring, summer and winter, while in males in autumn and winter.

\section{Authors declare no conflict of interest.}

Study was financed from research grant of the Ministry of Science and Higher Education/National Science Centre N308565240.

\section{References}

1. Anon.http://www.nauka.gov.pl/g2/oryginal/2013_05/ 91344c98ee12f19a3735d49716e9f643.pdf.

2. Pintor PP, Grassini V (1957): Individual and seasonal spontaneous variations of haematological values in normal male rabbits. Statistical survey. Acta Haematol 17: 122-128.

3. Chomicz L (1967): Pathological changes of blood depending on sex and age of rabbits experimentally infected with sheep strain of Strongyloides papillosus. Acta Parasitol Pol 14: 251-263.

4. Fox RR, Laird CW (1970): Diurnal variations in rabbits: hematological parameters. Am J Physiol 218: 1609-1612.

5. Laird CW, Fox RR, Mitchell BP, et al. (1970): Effect of strain and age on some hematological parameters in the rabbit. Am J Physiol 218: 1613-1617.

6. Bortolotti A, Castelli D, Bonati M (1989): Hematology and serum chemistry values of adult, pregnant and newborn new Zealand rabbits (Oryctolagus cuniculus). Lab Anim Sci 39: 437-439.

7. Jain JM (1994): Comparative hematologic features of some avian and mammalian species. In: Jain NC (ed.). Essentials of veterinary hematology. Lea and Febiger, Philadelphia, p. 367-376.

8. Deptuła W, Górecka-Odkała D, Tokarz-Deptuła B (1995): Dynamics of selected immunological parameters in 3-5 months old rabbits. Med Weter 51: 552-554.

9. Rohilla PP, Bujaubauah KM, Singh G, Kumar M (2000): Haematological and biochemical studies on pure and crossbred rabbits. Ind J Anim Sci 70: 60-62.

10. Nowaczyk P, Deptuła W, Tokarz-Deptuła B, et al. (2004): Dynamics of chosen immunological-haematological parameters in annual cycle in rabbits. Centaur Lubuski 61: 6-10.

11. Chineke CA, Ologun AG, Ikeobi CON (2006): Haematological parameters in rabbits breeds and crosses in humid tropics. Pak J Biol Sci 9: 2102-2106.

12. Olayemi FO, Nottidge HO (2007): Effect on the blood profiles of the New Zealand rabbit in Nigeria. Afr J Biomed Res 10: 73-76.

13. Archetti I, Tittarelli C, Ceriolo M, et al. (2008): Serum chemistry and hematology values in commercial rabbits: preliminary data from industrial farms in Northern Italy. In: $9^{\text {th }}$ World Rabbit Congress, Verona, Italy, p. 1147-1151.

14. Ezema WS, Omeke BCO, Eze JI, Nwanta JA (2009): Studies on the sexual behaviour, haematology and spermatogenesis of male rabbits infected with Trypanosoma brucei brucei. Comp Clin Pathol 18: 63-68.
15. Jeklova E, Leva L, Knotigova P, Faldyna M (2009): Age-related changes in selected haematology parameters in rabbits. Res Vet Sci 86: 525-528.

16. Çetin N, Bekyürek T, Çetin E (2009): Effects of sex, pregnancy and season on some haematological and biochemical blood values in angora rabbits. Scand J Lab Anim Sci 36: 155-162.

17. Poljičak-Milas N, Kardum-Skelin I, Vudan M, et al. (2009): Blood cell count analyses and erythrocyte morphometry in New Zealand white rabbits. Vet Arhiv 79: 561-571.

18. Martinec M, Härtlova H, Chodová D, et al. (2012): Selected haematological and biochemical indicators in different breeds of rabbits. Acta Vet Brno 81: 371-375.

19. Yaqub LS, Kawu MU, Ayo JO (2013): Influence of reproductive cycle, sex, age and season on haematologic parameters in domestic animals: a review. J Cell Anim Biol 7: 37-43.

20. Anon (1987): Information and training materials of the Laboratory Animals Section, General Assembly of the Association of Agriculture Engineers and Technicians, p. 26-77.

21. Anon (2006): Regulation of the Minister of Agriculture and Rural Development of 10 March 2006 on detailed conditions for maintenance of laboratory animals in experimental units, breeding units and suppliers. Polish Journal of Laws 50: item 368

22. Deptuła W, Kostrzewa A, Stosik M, et al. (1998): Subpopulations of peripheral blood lymphocytes in rabbits. Nowiny Lek 67: 377-382.

23. Deptuła W, Niedźwiedzka-Rystwej P, Śliwa J, et al. (2009): Specific immunity in healthy rabbits. Centr Eur J Immunol 34: 18-19.

24. Deptuła W, Tokarz-Deptuła B, Hukowska-Szematowicz B (2004): Lymphocytes and their subpopulations in peripheral blood of rabbits. In: VII Conf. "Molecular biology in diagnostics of infectious diseases and biotechnology", Warsaw, Poland, p. 55-58.

25. Deptuła W, Tokarz-Deptuła B, Hukowska B (2004): Subpopulations of lymphocytes in peripheral blood of healthy 3-to 3,5-month-old rabbits. In: $13^{\text {th }}$ Int. Symp. "Molecular and physiological aspects of regulatory processes of the organism", Kraków, Poland, p. 91-92.

26. Deptuła W, Tokarz-Deptuła B, Kostrzewa A, et al. (1998): Cytometric analysis of peripheral blood lymphocyte populations in healthy rabbits. In: Symp. "Animal Husbandry and Applied Biology", Wrocław, Poland, p. 169-171.

27. Tokarz-Deptuła B, Deptuła W (2005): Values of selected immune and haematological parameters in healthy rabbits. Pol J Vet Sci 8: 107-112.

28. Ferrian S, Guerrero I, Blas E, et al. (2012): How selection for reproduction or foundation for longevity could have affected blood lymphocyte populations of rabbit does under conventional and heat stress conditions. Vet Immunol Immunopath 150: $53-60$

29. Guerrero I, Ferrian S, Blas E, et al. (2011): Evolution of the peripheral blood lymphocyte subpopulations in multiparous rabbit does with two reproductive management rhytms. Vet Immunol Immunopathol 140: 75-81.

30. Jeklova E, Leva L, Faldyna M (2007): Lymphoid organ development in rabbits: major lymphocyte subsets. Dev Comp Immunol 31: 632-644.

31. Sabolović N, Sabolović D, Guilmin AM (1977): T and B cell surface markers on rabbit lymphocytes. Immunology 32 : 581-590. 